Arq. Bras. Med. Vet. Zootec., v.69, n.3, p.761-765, 2017

\title{
Communication
}

[Comunicação]

\section{Applicability of PCR-based clonality assay in dogs with multicentric lymphoma}

[Aplicabilidade do ensaio de clonalidade por PCR em cães com linfoma multicêntrico]

\author{
V. Nowosh, D.B. Macieira, N.X. Alencar* \\ Universidade Federal Fluminense - Niterói, RJ
}

Lymphoma is the most common hemolymphatic neoplasia in small animals. Diagnosis is based on malignant morphology criteria seen in cytopathology and histopathology slides (Burkhard and Bienzle, 2013). Phenotyping and staging may contribute to prognosis, but cannot be assessed only by morphologic diagnosis, requiring other diagnostic techniques (Bienzle and Vernau, 2011). Moreover, diagnosing neoplasia only by morphology can be challenging in some situations, such as in early stages of lymphoma, neoplasia involving more mature cells, chronic lymphoid leukemia and aspirates with few abnormal cells (Burnett et al., 2003).

PCR for Antigen Receptor Rearrangement Assay (PARR-assay) is a molecular-based tool with several applications for lymphoma and lymphoid leukemia diagnosis (Avery, 2012). PARR-assay targets receptor genes that, due to genetic rearrangement during lymphoid maturation present a unique size and sequence for each normal lymphocyte, However, neoplastic lymphocytes descend from a single clone, thus presenting receptor genes with same sequence and size. PARR-assay amplifies these receptor genes. Since normal and reactive lymphoid tissues have many lymphocytes with different sized receptors, PCR products tend to form polyclonal bands or smears after gel electrophoresis. Meanwhile, lymphoma PCR products form single bands, since most of the lymphocytes from the sample present a singlesized gene (Burnett et al., 2003).

Recebido em 18 de agosto de 2016

Aceito em 10 de outubro de 2016

*Autor para correspondência (corresponding author)

E-mail: nayro@vm.uff.br
As such, PARR-assay's main applicability is to differentiate neoplasia from reactive hyperplasia when microscopic evaluation does not confirm diagnosis (Avery, 2012; Burkhard and Bienzle, 2013), but it also provides useful information, such as phenotype and involvement of blood and bone marrow (Burnett et al., 2003; Keller et al., 2004; Lana et al., 2006). Furthermore, unlike other techniques, this can be performed using DNA extracted from air-dried stained fine needle aspiration cytopathology (FNAC) samples, archived for years, with reliable results (ŠtoosVeić et al., 2010).

There are still relatively few studies based on PARR-assay, and there are no previous studies described in Brazil. This study aimed at developing a PARR-assay protocol for canine lymphoma diagnosis based on already published studies and applying it in phenotyping cases of lymphoma from fresh samples and archived FNAC slides.

The protocol of this study was submitted and accepted by the Comissão de Ética no Uso de Animais of Universidade Federal Fluminense (UFF), under protocol n. ${ }^{\circ} 689$.

Lymph node aspirate samples were collected from ten canine patients diagnosed with multicentric lymphoma confirmed by FNAC with no history of previous treatment with chemotherapy. In addition, fifteen FNAC slides of lymph node from the hospital archives were also assessed for adequate material and included in this study. A reactive lymph node sample was used as negative control. 
Aspirate samples were submitted to extraction using Wizard ${ }^{\circledR}$ Genomic DNA Purification Kit (Promega, USA), following the manufacturer's guidelines for each sample. FNAC slide cells were recovered by using a scalpel blade. These samples were submitted to extraction using Invisorb ${ }^{\circledR}$ Spin Tissue Mini Kit (Stratec, Germany), following the manufacturer's guidelines. After extraction, DNA from each sample was quantified by using Quantifluor ${ }^{\circledR}$ (Promega, USA).

Amplification protocol and primers were based on the original study (Burnett et al., 2003). Four sets of primers were used: Two sets for detecting IgH segments (B-cell receptor clonality); one set for TCR $\gamma$ gene segments (T-cell receptor clonality); and one $\mathrm{C} \mu$ set to detect the constant region of $\mathrm{IgM}$ in order to ensure adequate and amplifiable lymphoid DNA in each sample, resulting in a single $130 \mathrm{bp}$ pcr-product. All samples were first tested for $\mathrm{C} \mu$ primer set. Only $\mathrm{C} \mu$-positive lymph-node samples were submitted to $\mathrm{IgH}$ and $\mathrm{TCR} \gamma$ primer sets to detect receptor clonality, since a negative result in $\mathrm{C} \mu$ indicates lack of amplifiable lymphoid DNA.

Each reaction consisted of $200 \mathrm{nM}$ of each primer and $5 \mu \mathrm{L}$ of DNA template, corresponding to at least $100 \mathrm{ng}$ of DNA. Polymerase used was GoTaq Flexi DNA polymerase ${ }^{\circledR}$ (Promega, USA). Minor changes were made to the original cycling profile. Samples were heated to $95^{\circ} \mathrm{C}$ for 5 minutes, then submitted to $94^{\circ} \mathrm{C}$ for $8 \mathrm{~s}, 60^{\circ} \mathrm{C}$ for $10 \mathrm{~s}$ and $72^{\circ} \mathrm{C}$ for $15 \mathrm{~s}$ for 35 cycles. Samples extracted from slides were submitted to 40 cycles in order to maximize final yield. Final extension time of $5 \mathrm{~min}$ at $72^{\circ} \mathrm{C}$ was used. PCR Products were then submitted to $12 \%$ polyacrilamide gel electrophoresis ( $1 \mathrm{~mm}$ thick) with $1 \mathrm{x}$ TAE buffer.

Following electrophoresis, gels were stained with ethidium bromide $0,5 \%$ and visualized under UV light. Positive reactions should show one, rarely two dominant clonal bands after electrophoresis. Negative reactions (or not clonal) show no bands, faint and multiple bands or a diffuse smear.

Amplification for $\mathrm{C} \mu$ were as shown in Figure 1.

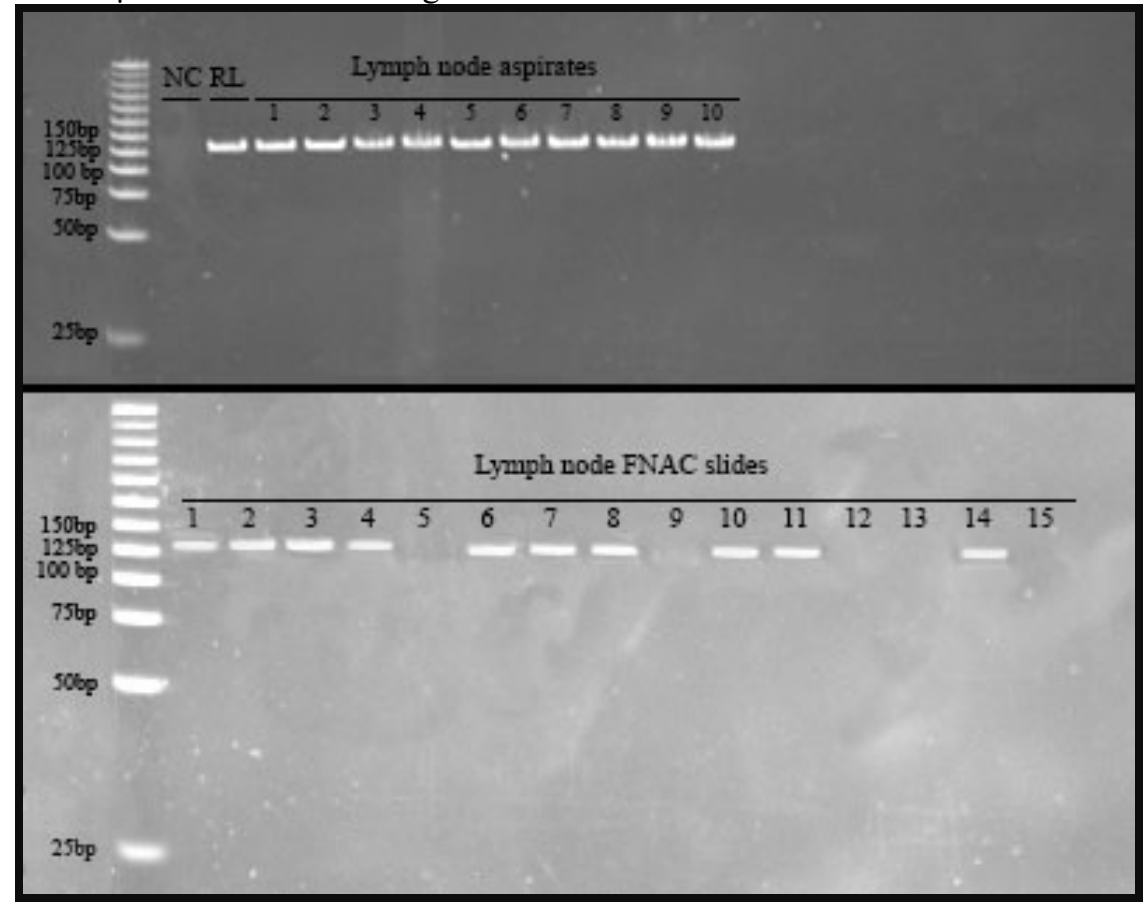

Figure 1. $\mathrm{C} \mu \mathrm{PCR}$ products on $12 \%$ polyacrilamide gel electrophoresis, presenting single bands with approximate size of $130 \mathrm{bp}$ that confirm lymphoid DNA in the sample. All 10 of lymph node aspirates had positive results, meanwhile only 10 of 15 samples from archived FNAC slides had positive results. $\mathrm{NC}=$ Negative Control. RL = Reactive lymph node. 
$\mathrm{C} \mu$ amplification had positive results in all ten aspirate samples, demonstrating adequate amount of lymphoid DNA for molecular analysis. However, 5/15 (33\%) of the FNAC slide samples from the archives had no detectable lymphoid DNA, even with the extended cycle protocol. A study by Štoos-Veić et al. (2010) using archived FNAC air-dried and stained lymph node and bone marrow slides for up to ten years of storage for molecular diagnosis achieved a good quality DNA for $100 \%$ of lymph node slides and $75 \%$ of bone marrow slides. Stained FNAC slides have proved to be as reliable as paraffin-embeded-tissues as a source of DNA for clonality assays even when presenting great numbers of naked nuclei (ŠtoosVeić et al., 2010). The reason of failure is not clear, but, probably, DNA yield following amplification was not enough to be detected, due to an already low yield of DNA after extraction.

Amplification for $\operatorname{IgH}$ and TCR $\gamma$ were then performed in the 20 samples positive for lymphoid DNA, and results were as shown in Table 1.

Table 1. PARR-assay phenotyping results in 20 canine lymphoma cases.

\begin{tabular}{lcccc} 
& \multicolumn{3}{c}{ PARR-assay phenotype } & \multirow{2}{*}{ Total } \\
\cline { 2 - 4 } Sample & B-cell & T-cell & Indeterminate & $10(50 \%)$ \\
Lymph node aspirate & $6(30 \%)$ & $2(10 \%)$ & $2(10 \%)$ & $10(50 \%)$ \\
Archived FNAC slides & $3(15 \%)$ & $4(20 \%)$ & $3(15 \%)$ & $20(100 \%)$ \\
\hline Total & $9(45 \%)$ & $6(30 \%)$ & $5(25 \%)$ & 20 \\
\hline
\end{tabular}

Reactive lymph node material has not shown clonality for any of the receptor genes and confirmed $\mathrm{B}$ and $\mathrm{T}$ lymph node samples have shown clonality for IgH and TCR $\gamma$ respectively, as expected. From all lymph node samples tested, 15/20 (75\%) demonstrated clonality, from which 9/15 (60\%) demonstrated clonality for IgH gene and $6 / 15(40 \%)$ for TCR $\gamma$ gene.

The PARR-assay is a sensible test for detecting phenotype, since a study comparing it with immunohistochemistry (IHC) and flow cytometry (FC), found out that PARR-assay, even though having a lower sensitivity than FC, is useful in detecting phenotype when IHC is not accessible-(Thalhein et al. 2013). Thus, it can be inferred that this study presented $60 \%$ of B-cell lymphomas and $40 \%$ of T-cell lymphomas. This possibly reflects a prevalence of B-cell lymphomas over T-cell lymphomas in the region of the study. This finding, if confirmed with greater sampling, is similar to those of other studies around the world (Thalhein et al., 2013).

Indeterminate results were found in 5/20 (25\%), demonstrating no receptor gene clonality, even though lymphoma was confirmed in cytopathology. Lymphomas with no receptor gene clonality are usually found in PARR-assay studies (Burnett et al., 2003; Lana et al., 2006;
Thilakaratne et al., 2010; Thalhein et al., 2013). This reflects the sensitivity of the primers in binding to the targeted regions, since rearrangement can result in a sequence of nucleotides that the primers cannot bind to. In addition, lymphomas with mutations on binding sites, deletion of receptor genes and NK-lineage lymphomas should also be considered (Burnett et al., 2003; Avery, 2012). Our study has shown an assay sensitivity of $75 \%$, which is similar to other studies (Lana et al., 2006; Thalhein et al. 2013).

It is worth noting that these primers were designed before the complete canine genome had become available. New IgH and TCR $\gamma$ primer sets based on the canine genome information were designed and have the potential to increase PARR assay overall sensitivity (Tamura et al., 2006; Yagihara et al., 2007), but should be further tested. In addition, the importance of rearrangements other than $\operatorname{IgH}$ and $\mathrm{TCR} \gamma$ in canine lymphomas should be assessed in order to maximize sensitivity and standardize PARRassay, following what was achieved in clonality assays for human lymphomas (Van Dongen et al., 2003).

In conclusion, we successfully applied the PARR-assay in our hospital routine diagnostics 
of lymphoma patients with a similar sensitivity achieved in previous studies. Positive samples have shown a prevalence of B-cell lymphomas in our region, but a larger sample size should be assessed to better confirm this statement. We suggest standardization of the technique to increase overall technique sensitivity. Currently, our intent is to enhance sample size for both fresh samples and FNAC slides, to raise data about lymphoma phenotypes in our region, and to include blood and bone marrow samples in order to evaluate PARR-assay staging potential.

Keyword: IgH receptor, molecular diagnostics, PARR-assay, TCR-gamma receptor

\section{RESUMO}

Linfoma multicêntrico apresenta alta prevalência dentre as neoplasias em cães, e o diagnóstico rotineiro não é eficaz para avaliação de prognóstico. A PCR para rearranjos de receptores de antígeno (PRRA) apresenta potencial para classificação e estadiamento de linfomas. Este trabalho objetiva relatar o desenvolvimento de um protocolo de PRRA para aplicação em cães, baseando-se em condições e primers descritos na literatura. Foram coletados aspirados de linfonodo de 10 cães com linfoma multicêntrico e 15 lâminas de linfonodo positivas para linfoma já secas ao ar, fixadas e coradas. O protocolo utilizado demonstrou-se eficaz na amplificação de DNA das amostras frescas e das lâminas, com sensibilidade de $75 \%$, similar à de estudos anteriores. Resultados parciais sugerem prevalência de linfomas de células $B$ (60\%) sobre células $T$ (40\%). O presente estudo abre precedentes para uma série de novos estudos com diagnóstico molecular de linfomas.

Palavras-chave: receptor IgH, diagnóstico molecular, ensaio de PRRA, receptor TCR-gama

\section{ACKNOWLEDGEMENTS}

The authors thank Joylson de Jesus Pereira, Tatiana Xavier de Castro, Fernanda Nahoum Carestiato and Ledy do Horto dos Santos Oliveira from Instituto Biomédico (UFF) for technical support.

\section{REFERENCES}

AVERY, A.C. Molecular diagnostics of hematologic malignancies in small animals. Vet. Clin. N. Am. Small Anim. Pract., v.42, p.97-110, 2012.

BIENZLE, D.; VERNAU, W. The diagnostic assessment of canine lymphoma: implications for treatment. Clin. Lab. Med., v.31, p.21-39, 2011.

BURKHARD, M.J.; BIENZLE, D. Making sense of lymphoma diagnostics in small animal patients. Vet. Clin. N. Am. Small Anim. Pract., v.43, p.1331-1347, 2013.

BURNETT, R.C.; VERNAU, W.; MODIANO, J.F. et al. Diagnosis of canine lymphoid neoplasia using clonal rearrangements of antigen receptor genes. Vet. Pathol., v.40, p.32-41, 2003.
KELLER, R.L.; AVERY, A.C.; BURNETT, R.C. et al. Detection of neoplastic lymphocytes in peripheral blood of dogs with lymphoma by polymerase chain reaction for antigen receptor gene rearrangement. Vet. Clin. Pathol., v.33, p.145-149, 2004.

LANA, S.E.; JACKSON, T.L.; BURNETT, R.C. et al. Utility of polymerase chain reaction for analysis of antigen receptor rearrangement in staging and predicting prognosis in dogs with lymphoma. J. Vet. Intern. Med., v.20, p.329-334, 2006.

ŠTOOS-VEIĆ, T.; LIVUN, A.; AJDUKOVI, R. et al. Detection of $\mathrm{t}(14 ; 18)$ by PCR of IgH/BCL2 fusion gene in follicular lymphoma from archived cytological smears. Coll. Antropol., v.34, p.425-429, 2010.

TAMURA, K.; YAGIHARA, H.; ISOTANI, M. et al. Development of the polymerase chain reaction assay based on the canine genome database for detection of monoclonality in B cell lymphoma. Vet. Immunol. Immunopathol., v.110, p.163-167, 2006. 
THALHEIN, L.; WILLIAMS, L.E.; BORST, L. et al. Lymphoma immunophenotype of dogs determined by immunohistochemistry, flow cytometry, and polymerase chain reaction for antigen receptor rearrangements. J. Vet. Intern. Med., v.27, p.1509-1516, 2013.

THILAKARATNE， D.N.; MAYER, M.N.; MACDONALD, V.S. et al. Clonality and phenotyping of canine lymphomas before chemotherapy and during remission using polymerase chain reaction (PCR) on lymph node cytologic smears and peripheral blood. Can. Vet. J., v.51, p.79-84, 2010.
VAN DONGEN, J.J.M.; LANGERAK, A.W.; BRÜGGERMANN, M. et al. Design and standardization of PCR primers and protocols for detection of clonal immunoglobulin and T-cell receptor gene recombinations in suspect lymphoproliferations: report of the BIOMED-2 Concerted Action BMH4-CT98-3936. Leukemia, v.17, p.2257-2317, 2003.

YAGIHARA, H.; TAMURA K.; ISOTANI, J. et al. Genomic organization of the T-cell receptor gene and PCR detection of its clonal rearrangement. Vet. Immunol. Immunopathol., v.115, p.375-382, 2007. 